1 Samantha V. Beck* ${ }^{1}$, Gary R. Carvalho ${ }^{2}$, Ian $\mathrm{McCarthy}^{3}$, Walter Hanks ${ }^{4}$, Robert Evans ${ }^{4}$,

2 Robert Edwards ${ }^{4}$, Martin Taylor ${ }^{5}$, Mark de Bruyn ${ }^{2,6}$

3

4 Genetic insights into the management and conservation of Arctic charr in North Wales

$6{ }^{1}$ The Rivers and Lochs Institute, University of the Highlands and Islands, Inverness, IV2

$7 \quad 5 \mathrm{NA}, \mathrm{UK}$

$8{ }^{2}$ Molecular Ecology and Fisheries Genetics Laboratory, School of Natural Sciences,

9 Environment Centre Wales, Bangor University, Bangor, LL57 2UW, UK

$10{ }^{3}$ School of Ocean Sciences, College of Environmental Sciences and Engineering, Bangor

11 University, Menai Bridge, Gwynedd, LL59 5AB, UK

$12{ }^{4}$ Natural Resources Wales, Maes y Ffynnon, Bangor, LL57 2DW, UK

$13{ }^{5}$ University of East Anglia, Norwich Research Park, Norwich, Norfolk, NR4 7TJ, UK

$14{ }^{6}$ The University of Sydney, School of Life and Environmental Sciences, Sydney, NSW 2006,

15 Australia

$16 *$ Corresponding author; e-mail: beck@mail.holar.is

\title{
18 Acknowledgments
}

19 We thank those at Natural Resources Wales and Bangor University who were involved in the

20 collection of samples. Thanks also to the Knowledge Economy Skills Scholarship for funding

21 and providing support for the research. 


\section{Abstract}

27 Aquatic species throughout the world are threatened by extinction in many parts of their 28 range, particularly in their most southerly distributions. Arctic charr (Salvelinus alpinus) is a

29 Holarctic species with a distribution that includes the glacial lakes of North Wales, towards it

30 southern limit. To date, no genetic studies have been conducted to determine the genetic

31 health of the three remaining native Arctic charr populations in North Wales, despite

32 exposure to stocking and adverse environmental and ecological conditions. We used seven

33 microsatellite loci to determine whether: 1) genetic differentiation existed between native

34 populations; 2) translocated populations from Llyn Peris were genetically similar to the

35 historically connected Llyn Padarn population; and 3) hatchery supplementation negatively

36 impacted genetic diversity in Llyn Padarn. All three native populations retained their genetic

37 integrity, with Llyn Bodlyn showing high levels of divergence $\left(\mathrm{F}_{\mathrm{ST}}=0.26 \pm 0.02 \mathrm{SD}\right)$ as well

38 as low genetic diversity $\left(\mathrm{H}_{\mathrm{O}} 0.30\right)$ compared to remaining populations $\left(\mathrm{H}_{\mathrm{O}} 0.64 \pm 0.14 \mathrm{SD}\right)$.

39 Although evidence suggests that stocking increased the effective population size of Llyn

40 Padarn in the short term without impacting genetic diversity, the long term effects of such

41 practices are yet to be seen. Results provide baseline data for conservation management, and

42 highlight the need for protection of small isolated populations that are being negatively

43 impacted by the processes of genetic drift due to escalating anthropogenic pressures.

44 Continual monitoring of both Arctic charr and their habitats using a combination of methods

45 will increase the likelihood that these threatened and iconic populations will persist in the 46 future.

48 Keywords

49 Fisheries management; freshwater; microsatellites; stocking; hatchery supplementation;

50 conservation. 


\section{Declarations}

\section{Funding}

54 This manuscript was funded by the Knowledge Economy Skills Scholarship for Wales

55 (KESS BU Mini 068). Sample collection by IDM was financed with the support of the

56 European Union ERDF - Interreg IIIB ‘Atlantic Area’ (project 091: SEAFARE).

\section{Conflicts of interest/Competing interests}

59 The authors declare that they have no conflict of interest.

60

\section{Ethics approval}

62 Samples were collected under licenses granted by Natural Resource Wales (NRW; previously

63 the Environment Agency Wales). NRW collected finclips from Arctic charr as part of a

64 normal sampling scheme, a recognised agricultural/husbandry practice performed in

65 accordance with other animal welfare for the purposes of managing and conserving the

66 animals, and have confirmed that this is not a regulated procedure under the Animals

67 (Scientific Procedures) Act.

68

69 Consent to participate

$70 \quad$ Non applicable

72 Consent for publication

73 Non applicable

\section{Availability of data and material}


76 Data will be made available on Dryad upon publication of the manuscript

77

78 Code availability

79 Non applicable

80

81 Authors' contributions

82 MT, GRC and MdB conceptualised and designed the study. Samples were collected by WH,

83 IM, RE and RE. Data collection and analysis were performed by SVB. The first draft of the

84 manuscript was written by SVB and all authors commented on subsequent versions of the

85 manuscript. All authors read and approved the final manuscript.

86

87

88

89

90

91

92

93

94

95

96

97

98

99 


\section{Introduction}

103 Earth's rich biota is in dramatic decline, with human-induced environmental change being

104 one of the most significant causes of species extinctions. Biodiversity loss is mostly centred

105 around numbers of described species, which may misrepresent the severity of such declines.

106 When focussing on the number of populations, however, results from terrestrial ecosystems

107 show that population extinctions are much greater than species extinctions (Ceballos et al.

108 2017), suggesting that we have already entered the sixth mass extinction. Freshwater

109 ecosystems are comparatively less well studied. Freshwaters comprise only $0.01 \%$ of the

110 Earths' water, covering just $2.3 \%$ of terrestrial areas, yet harbour $9.5 \%$ of all known animal

111 species globally, including one-third of vertebrates (Balian et al. 2008). These remarkably

112 rich ecosystems are experiencing declines in biodiversity that are far greater than those of

113 either terrestrial or marine ecosystems (WWF, 2016). Indeed, the IUCN red list have recently

114 assessed half of the worlds' known freshwater fish species, one third of which were

115 categorised as threatened with extinction (IUCN 2019).

116 Environmental stressors such as pollution, temperature change, habitat destruction,

117 and overexploitation can result in small isolated populations that are increasingly subject to

118 genetic drift and inbreeding due to declining effective population sizes, resulting in a loss of

119 genetic variation and a decrease in fitness (Hauser et al. 2002; Nowak et al. 2009;

120 Ursenbacher et al. 2009; Gomaa et al. 2011). For example, the construction of hydropower

121 stations have removed spawning sites and migratory routes for various salmonid populations

122 that rely heavily upon freshwater connectivity, due to their high natal philopatry (Mathers et

123 al. 2002; Maitland et al. 2007). Translocations of entire populations across landscapes are

124 often used as a tool to mitigate various anthropogenic stressors and maintain biodiversity 
125 (genetic diversity), or increase the number or size of populations under threat (Weeks et al.

126 2011). However, the movement of populations from native to non-native habitats can often

127 result in low fitness levels due to the disruption of local adaptation, thus having a major

128 impact on the genetic composition and evolutionary trajectories on wild populations

129 (Allendorf et al. 2008; Valiquette et al. 2014).

130 Stocking practices are another important conservation management tool that aims to

131 alleviate such genetic erosion in fishes, yet the introduction of foreign genetic material, i.e.

132 through the release of translocated and/or hatchery-reared individuals, may negatively impact

133 the evolutionary potential and genetic integrity of populations (Araki et al. 2008; Laikre et al.

134 2010; Perrier et al. 2013; Quiñones et al. 2014; Valiquette et al. 2014), even within a single

135 generation (Araki et al. 2007a; Christie et al. 2012b). Salmonids are some of the most

136 intensively propagated species in hatchery stocking programs (Lackey et al. 2006), due in

137 part to their socio-economic importance. Despite the importance of intraspecific diversity for

138 a species' resilience to environmental change (Sgrò et al. 2011; Pauls et al. 2013), many

139 salmonid populations across their native range in the northern hemisphere are experiencing

140 unprecedented declines (Winfield et al. 2010; ICES 2019). The capability of hatchery

141 programmes in maintaining both genetic diversity and fitness in the wild over the long term is

142 uncertain (Fraser 2008; Christie et al. 2012a).

143 The Holarctic distribution of Arctic charr makes this salmonid species particularly

144 vulnerable to rising temperatures and increasing anthropogenic pressures, especially at their

145 southern extremes (Kovach et al. 2019; Muhlfeld et al. 2019). Numerous translocations and

146 hatchery supplementations of Arctic charr ('Torgoch') in North Wales have occurred as a

147 response to the negative impacts these environmental and anthropogenic pressures have had

148 on natural charr populations. There were originally four known native populations of Arctic

149 charr in North Wales: Llyn(-lake) Padarn, Llyn Peris, Llyn Cwellyn and Llyn Bodlyn (Fig. 
150 1). However, the construction of the Dinorwig power station in 1974 saw the translocation of

151 Arctic charr from Llyn Peris (the type locality for Salvelinus alpinus perissi; Günther, 1862)

152 to Ffynnon Llugwy and Llyn Dulyn after allozyme evidence suggested no genetic

153 differentiation between Arctic charr from Llyn Peris and those from Llyn Padarn (Child

154 1977). Not only did this construction result in the extirpation of Llyn Peris charr, but also

155 removed spawning habitat for Arctic charr in Llyn Padarn, which were believed to migrate

156 into Llyn Peris to spawn (Butterworth 1980). Given the high productivity of Llyn Padarn and

157 the propensity of Arctic charr to diverge along trophic resource gradients (Skúlason et al.

158 1999), as well as evidence that both populations differed in size and parasite abundance

159 (McCarthy 2007), it is likely that Arctic charr in Llyn Padarn and Llyn Peris exhibited, to

160 some extent, parapatric divergence both phenotypically (McCarthy 2007) and genetically.

161 Since the construction of Dinorwig power station, numerous translocations of Arctic charr to

162 lakes that are deeper and at higher altitudes have been conducted across North Wales, where

163 there now exist not only three native populations, but also six translocated populations (see

164 reviews by (Maitland et al. 2007; McCarthy 2007; Ferguson et al. 2019). Although Child

165 (1977) found genetic differentiation between the native populations (Llyn Padarn/Peris, Llyn

166 Cwellyn and Llyn Bodlyn), no genetic study using DNA-based molecular markers has since

167 been conducted on these Welsh Arctic charr populations, and their status remains unknown.

168 In Llyn Padarn, for example, a sharp decline of Arctic charr in 2009 due to a toxic algal

169 bloom (amongst various other anthropogenic stressors; (White 2012; Clabburn et al. 2014;

170 Hatton-Ellis 2016) resulted in the establishment of a back-up population in Llyn Crafnant,

171 from a broodstock created from a total of 77 females and 54 males (from 2009-2013; Table

172 1) from Llyn Padarn for use in a hatchery supplementation programme. However, the effects

173 of such stocking practices remain unclear and may potentially have a negative impact on the

174 wild population (Araki and Schmid 2010). 
175 This study aims to understand how both historic and contemporary management

176 practices have influenced the genetic variability of small freshwater populations. Using seven

177 microsatellite markers, we specifically asked whether: 1) genetic differentiation and genetic

178 integrity exists between all three remaining native populations of Arctic charr in North

179 Wales; 2) translocated Arctic charr from Llyn Peris were genetically similar to Arctic charr in

180 Llyn Padarn; and 3) stocking of hatchery-reared charr reduced the genetic variability of the 181 wild population in Llyn Padarn.

\section{Methods}

\section{Sample collection}

185 A total of 307 individuals (fin clips) from eight lakes in North Wales (Fig. 1) were used in

186 this study (see Table 2 for lake information and Table 3 for sample sizes). Fyke nets were 187 placed near the entrance to the Afon-y-Bala (Fig. 1b) in Llyn Padarn as part of Natural

188 Resources Wales (NRW) hatchery-supplementation programme. Fin clips were taken and 189 stored in $96 \%$ ethanol from each individual after stripping had occurred. The fertilised eggs 190 were then reared in Mawddach hatchery and subsequently released into Llyn Crafnant as a 191 secondary population for Llyn Padarn (Table 1). All other populations were also sampled 192 using fyke nets by McCarthy in 2008 and stored in 96\% ethanol, until DNA extractions were 193 conducted in 2013.

195 DNA extractions

196 DNA was extracted from adipose fin clippings for all 307 individuals using the CTAB 197 (hexadecyltrimethyammonium bromide) extraction method. Samples were suspended in 198 CTAB extraction buffer: $100 \mathrm{mM}$ Tris- $\mathrm{HCl} \mathrm{pH} 8.0 ; 1.4 \mathrm{M} \mathrm{NaCl} ; 20 \mathrm{mM}$ EDTA pH 8.0; $2 \%$

$199 \mathrm{CTAB} ; 0.2 \%$ 2-mercaptoethanol, and $0.1 \mathrm{mg} / \mathrm{ml}$ of proteinase $\mathrm{K}$ was added to digest the 
200 samples overnight at $60^{\circ} \mathrm{C}$. Two chloroform:isoamylalcohol washes were then performed

201 followed by sodium acetate precipitation (3M, pH4.8), and one wash of $70 \%$ ethanol before

202 DNA extracts were suspended in ultrapure $\mathrm{H}_{2} \mathrm{O}$ and stored at $-20^{\circ} \mathrm{C}$.

\section{DNA amplification and genotyping}

205 All 307 individuals were analysed at eight microsatellite loci using QiagenType-it Multiplex

206 PCR kit. Each $10 \mu \mathrm{l}$ multiplex reaction contained at least $2 \mathrm{ng} / \mu \mathrm{l}$ DNA template, $2.5 \mu \mathrm{l}$

207 QiagenType-it Multiplex reaction buffer, 50mg/ml Bovine Serum Albumin (BSA) due to

208 potential degradation of DNA, and primers at different concentrations (Table S1). PCR

209 conditions were the same for both multiplexes, and began with an initial $95^{\circ} \mathrm{C}$ activation step,

210 followed by 34 cycles of 30 s at $94^{\circ} \mathrm{C}, 90$ s at $57^{\circ} \mathrm{C}$, and 60 s at $72^{\circ} \mathrm{C}$, followed by 31 cycles of

$21130 \mathrm{~s}$ at $94^{\circ} \mathrm{C}, 90 \mathrm{~s}$ at $50^{\circ} \mathrm{C}$, and $60 \mathrm{~s}$ at $72^{\circ} \mathrm{C}$, and finalised with a $30 \mathrm{~min}$ extension phase at

$21260^{\circ} \mathrm{C}$. A subset of amplified products were migrated via electrophoresis, and then all samples

213 were run on the Applied Biosystems ABI 3130xl Genetic Analyser, and microsatellite allele

214 sizes scored using GENEMAPPER 3.0 (Applied Biosystems).

\section{Genetic diversity}

217 Unless otherwise stated, all analyses were conducted in R (R Core Team 2016). The presence

218 of null alleles were determined using the package PopGenReport v3.0.4 (Adamack and

219 Gruber 2014), as well as the identification of any private alleles ( $\left.\mathrm{A}_{\text {private }}\right)$. For each individual

220 locus, observed $\left(\mathrm{H}_{\mathrm{O}}\right)$ and expected $\left(\mathrm{H}_{\mathrm{E}}\right)$ heterozygosities were calculated using the adegenet

221 package (Jombart 2008), whilst hierfstat (Goudet 2005) and PopGenReport (Adamack and

222 Gruber 2014) was used to calculate inbreeding coefficients ( $\left.\mathrm{F}_{\mathrm{IS}}\right)$ with bootstrapping over loci

223 to provide confidence intervals for each population, and rarified allelic richness $\left(\mathrm{A}_{\mathrm{r}}\right)$,

224 respectively. The package pegas (Paradis 2010) was used to test for deviations from Hardy- 
225 Weinberg equilibrium (HWE) for each locus. The diveRsity package (Keenan et al. 2013)

226 was used to calculate several genetic parameters across loci: $\mathrm{A}_{\mathrm{r}}$ with rarefaction; $\mathrm{F}_{\mathrm{IS}}$ using

22710,000 bootstrap replicates across individuals were used to generate $95 \%$ confidence

228 intervals; $\mathrm{H}_{\mathrm{O}}$ and $\mathrm{H}_{\mathrm{E}}$; global $\mathrm{HWE}(\mathrm{glb})$ based on log-likelihood tests for goodness of fit using

229 10,000 Monte Carlo replicates; one-tailed tests for heterozygosity deficiency (HWE(hom))

230 and heterozygosity excess (HWE(het)).

232 Population structure

233 The extent of genetic differentiation between populations was quantified using Nei's pairwise

$234 \mathrm{~F}_{\mathrm{ST}}$ (Nei 1973) in the package hierfstat (Goudet 2005), with 10,000 bootstraps over loci of

235 pairwise $\mathrm{F}_{\mathrm{ST}}$ to determine confidence intervals. Hierarchical analyses of molecular variance

236 (AMOVA; Excoffier et al., 1992) was used to determine the source of genetic differentiation,

237 using the package ade4 (Dray and Dufour 2007). This approach partitions variance into

238 covariance components to calculate Phi's ' $\Phi$ ' fixation indices for various hierarchical levels.

239 We conducted two AMOVAs, the first of which had two hierarchical levels: 1) populations,

240 and 2) stocking status (e.g. stocked versus unstocked). Neither the Crafnant hatchery

241 population, nor the Padarn population after stocking were included in this part of the analyses

242 as their potential genetic similarities were likely to bias results. The second AMOVA used

243 data from Llyn Padarn only to test for differences in variation before and after stocking.

244 Significance was tested using 1,000 permutations.

245 The Bayesian clustering programme STRUCTURE (Pritchard et al. 2000) was

246 implemented within stratag (Archer et al. 2017) without admixture due to the landlocked

247 status of each population and the lack of resident Arctic charr in those translocated lakes. A

248 burn-in period was set to 100,000 and 100,000 Markov Chain Monte Carlo (MCMC)

249 iterations, with $k$ ranging from 2-9. The best $k$ was chosen according to $\Delta \mathrm{k}$ (Evanno et al. 
250 2005) and ggplot (Wickham 2016) was used to plot STRUCTURE outputs. Finally,

251 Discriminate Analysis of Principal Components (DAPC) were performed within adegenet

252 (Jombart 2008) to describe the relationships between each genetic cluster at two levels: 1)

253 between all clusters identified from STRUCTURE; and 2) between the hatchery stock

254 (Crafnant) and the Padarn populations before (Padarn08) and after (Padarn13) hatchery

255 supplementation.

257 Effective population size and bottlenecks

258 Effective population size $\left(\mathrm{N}_{\mathrm{e}}\right)$ was estimated using the linkage disequilibrium method in

259 native populations only, due to the potential bias caused by population admixture in those

260 translocated populations (Araki et al. 2007b; Waples and Do 2010). Such estimates were

261 implemented using the linkage disequilibrium method within the software NeEstimator v2.0

262 (Do et al. 2014). In a population that has reduced in size, genetic drift is more likely to have

263 resulted in the loss of rare alleles than common alleles. As such, the ratio of microsatellite

264 allele number to microsatellite allele size range ( $M$; Garza and Williamson, 2001) is expected

265 to be reduced following a population bottleneck. We therefore used the programme M_P_Val

266 (Garza and Williamson, 2001) to determine whether populations have experienced a recent

267 bottleneck, evident through smaller $M$ in relation to equilibrium expectations. Using

268 recommended paramenters by Garza and Williamson (2001), we used a two-phase mutation

269 model with $90 \%$ single-step mutations, with the average size of multi-step mutations being

2703.5 repeat units. We assumed a microsatellite mutation rate of $5 \times 10^{-4}$ (Garza and

271 Williamson 2001) and removed all monomorphic loci from the analysis. The $\mathrm{N}_{\mathrm{e}}$ of

272 populations before any reduction in size is unkown, therefore the analysis was run using a

273 range of suitable $\mathrm{N}_{\mathrm{e}}$ estimates: $\mathrm{N}_{\mathrm{e}}=250(\Theta=0.5) ; \mathrm{N}_{\mathrm{e}}=500(\Theta=1)$; and $\mathrm{N}_{\mathrm{e}}=1000(\Theta=2)$. 
274 Evidence of a population decline was indicated if $<5 \%$ of the 10,000 simulated replicates fell

275 below the critical M value $\left(M_{\mathrm{c}}\right)$, calculated using Critical_M (Garza and Williamson 2001).

\section{Results}

\section{Genetic diversity}

279 The only locus that was removed due to the presence of null alleles was SalE38. Although

280 Crafnant had population-specific null alleles for SalD39 and Ssa406, their removal did not 281 change the results and they were therefore retained within the analyses, leaving a total of 282 seven microsatellite loci. The total number of alleles observed per locus ranged from seven 283 (SalF56) to 35 (SsaD48), with a mean of 18.14 (Table S2). Bodlyn exhibited fixed alleles at 284 two loci: SalF56 and SalJ81, and also had the lowest mean $A_{r}$ (3.39) across all populations, 285 with Padarn08 having the highest mean $A_{r}(6.68)$, with mean rarified $A_{R}$ of $5.70( \pm 0.97, S D)$. 286 Such patterns were also reflected in expected levels of heterozygosity (Table 3), with Bodlyn 287 having the lowest $\mathrm{H}_{\mathrm{e}}(0.39)$ and Padarn08 having the highest $\mathrm{H}_{\mathrm{e}}(0.76)$ levels compared to the 288 overall average of $0.68( \pm 0.11, \mathrm{SD})$. Bodlyn also shows the highest $\mathrm{F}_{\mathrm{IS}}$ values $(0.28$; albeit 289 not significant).

290 Of the nine populations examined, eight exhibited significant deviations from HWE.

291 Only Diwaunedd showed no deviations from HWE, but this population also had the lowest 292 sample size $(\mathrm{N}=11)$. Seven of the remaining populations deviated from $\mathrm{HWE}$ as a result of an 293 excess of heterozygosity (Bodlyn, Cowlyd, Crafnant, Cwellyn, Dulyn, Fynnon Llugwy and 294 Padarn13), whilst Padarn08 deviated from HWE as a result of heterozygote deficiency as 295 well as heterozygote excess (Table 1). 
298 Results showed the native Bodlyn population to be highly differentiated from all other

299 populations (Table 4). Estimates of global $\mathrm{F}_{\mathrm{ST}}$ amongst all nine populations was 0.16, with

300 pairwise differences between Llyn Bodlyn and all other populations averaging $0.26( \pm 0.02$,

301 SD). A translocated population, Llyn Dulyn, also showed significant genetic differentiation

302 between all populations except Diwaunedd and Padarn08, with an average $F_{\text {ST }}$ of $0.07( \pm 0.10$,

303 SD). There was no genetic differentiation between Padarn before (Padarn08) or after

304 (Padarn13) stocking, nor was there any differences compared with the hatchery population

305 (Crafnant). Excluding Llyn Crafnant and Padarn13, AMOVAs revealed that genetic

306 differentiation between the stocked (i.e. translocated) versus unstocked populations (i.e.

307 native) explained $6.87 \%$ of the total variance, populations explained $14.88 \%$, and between

308 individuals within a population and within individuals explained $8.22 \%$ and $70.03 \%$,

309 respectively (all $P<0.05$; Table 5). When examining the effects of hatchery supplementation

310 on Llyn Padarn charr, AMOVAs found $2.96 \%(P<0.001)$ differences in genetic

311 differentiation before and after supplementation $\left(\mathrm{F}_{\mathrm{ST}}\right)$ (Table 5; Fig. S1). Whilst variation

312 between individuals within populations $\left(\mathrm{F}_{\mathrm{IS}}\right)$, and variation within individuals $\left(\mathrm{F}_{\mathrm{IT}}\right)$ showed

313 no differences (Table 5).

314 For STRUCTURE analysis, the most likely number of clusters identified by $\Delta \mathrm{k}$ was $k=$

315 3. Each of these three genetic clusters corresponded to one of the three remaining native

316 populations: Bodlyn, Padarn and Cwellyn (Fig. 2a). All three native populations seem to have

317 conserved their genetic integrity, as shown by both DAPC and STRUCTURE plots (Fig. 2). The

318 Diwaunedd stock seems to have primarily originated from Llyn Cwellyn (Fig. 2a), but the

319 small sample size $(\mathrm{N}=11)$ likely prevents its clear clustering, and it is instead situated

320 inbetween Padarn and Cwellyn (Fig. 2b). Although the hatchery Crafnant population

321 primarily consists of genotypes from Llyn Padarn, there also appears to be some genotypes 
322 from Llyn Cwellyn as well (Fig. 2a). However, such patterns were not reflected within the

323 DAPC (Fig. 2b).

324

325 Estimates of effective population size and bottlenecks

326 Estimates of $\mathrm{N}_{\mathrm{e}}$ for native populations varied from as little as five for Padarn08 (before

327 hatchery supplementation), to 306 for Llyn Bodlyn. Llyn Cwellyn had an $\mathrm{N}_{\mathrm{e}}$ of 35, whilst

328 Padarn13 (after hatchery supplementation) was estimated at 54 (Table 3). All populations,

329 both native and translocated, show evidence of a population bottleneck or founder effects,

330 respectively $(P<0.001)$, with $M$ ratios $(M: 0.219-0.332)$ showing a lower value than

331 expected under equilibrium conditions $\left(M_{\mathrm{c}}: 0.696-0.718\right)$, regardless of $\mathrm{N}_{\mathrm{e}}$ before population

332 size reduction (Table 3).

\section{Discussion}

335 Despite stocking practices and numerous translocations of Arctic charr between lakes in

336 North Wales, the population genetic structure amongst the three remaining native populations

337 has been retained. Hatchery supplementation of the declining native Llyn Padarn population

338 has increased effective population size $\left(\mathrm{N}_{\mathrm{e}}\right)$ in the short term, but at the cost of a reduction in

339 the number of private alleles, i.e. loss of genetic uniqueness (Table 4). All three native

340 populations have retained their genetic integrity, yet the isolated location of Llyn Bodlyn has

341 likely exposed this population to genetic drift, evident through low levels of genetic diversity.

342 All populations show evidence for a recent population bottleneck or, for those translocated

343 populations, founder effects. This study highlights the need to further conserve the genetic

344 diversity of Arctic charr in North Wales, especially in Llyn Bodlyn where there is currently

345 no conservation protection, despite harbouring a highly divergent and vulnerable native

346 population of Arctic charr. 


\section{Genetic diversity in an isolated population}

349 All populations of Arctic charr in North Wales - with the exception of Llyn Bodlyn $\left(\mathrm{H}_{\mathrm{O}}=\right.$

$\left.350 \quad 0.30 ; A_{R}=3.39\right)-$ showed moderate-high levels of genetic diversity $\left(H_{O}=0.68 \pm 0.06 ; A_{R}=\right.$

$3515.99 \pm 0.47$; Table 3) compared to other British Arctic charr populations $\left(\mathrm{H}_{\mathrm{O}}=0.58 \pm 0.15\right.$

$352 \mathrm{SD} ; \mathrm{A}_{\mathrm{R}}=6.52 \pm 2.51 \mathrm{SD}$; Wilson et al., 2004). The high genetic differentiation of Llyn

353 Bodlyn $\left(\mathrm{F}_{\mathrm{ST}}=0.26 \pm 0.02 ; P<0.05\right)$ reflects its isolated position $(\sim 50 \mathrm{~km}$ from the nearest

354 population) as well as its relatively high elevation $(385 \mathrm{~m})$, which is three-times higher than

355 all other native populations (Table 2). Although such elevation might buffer against

356 increasing temperatures (Roberts et al. 2013), Llyn Bodlyn is the smallest (16ha) and

357 shallowest $(22 \mathrm{~m})$ of all Arctic charr lakes in North Wales. Furthermore, this lake is also a

358 reservoir that can have up to $60 \%$ of its storage drained in periods of drought (plus more in

359 severe cases; (DCWW 2015)), leaving little suitable habitat for Arctic charr during hot

360 summer periods. These small isolated populations are most vulnerable to the negative

361 impacts of genetic drift, reducing heterozygosity and increasing levels of inbreeding (Reed

362 and Frankham 2003), especially when exposed to such stochastic environmental changes.

363 Here we suggest that Llyn Bodlyn has been subject to such processes, evident from the low

364 levels of heterozygosity $\left(\mathrm{H}_{\mathrm{O}}=0.30\right)$, allelic richness $\left(\mathrm{A}_{\mathrm{R}}=3.39\right)$ and high inbreeding

365 coefficient $\left(\mathrm{F}_{\mathrm{IS}}=0.28\right)$ compared to the overall mean for all populations $\left(\mathrm{H}_{\mathrm{O}}=0.64 \pm 0.14\right.$

$366 \mathrm{SD} ; \mathrm{A}_{\mathrm{R}}=5.70 \pm 0.97 \mathrm{SD} ;$ and $\mathrm{F}_{\mathrm{IS}}=0.10 \pm 0.09 \mathrm{SD}$; see Table 3). Nevertheless, estimates of

$367 \mathrm{~N}_{\mathrm{e}}$ are high (307) compared to other native populations such as Llyn Cwellyn $\left(\mathrm{N}_{\mathrm{e}}=35\right)$,

368 suggesting that habitat limitations on population size have, over a long period of time,

369 reduced the genetic variability of this isolated population (Franklin 1980). It is important to

370 note that whilst estimates of $\mathrm{N}_{\mathrm{e}}$ are a valuable measure for conservation management,

371 assumptions around $\mathrm{N}_{\mathrm{e}}$ values are often violated in nature (i.e. no selection, migration, 
372 mutation and discrete generations). Almost all populations in this study deviate from Hardy-

373 Weinberg equilibrium (HWE), and as such, estimates of $\mathrm{N}_{\mathrm{e}}$ should be approached with

374 caution.

\section{Genetic integrity}

377 All three native populations of Arctic charr retained their genetic differentiation and integrity

378 (Fig. 2; Table 4), with Llyn Cwellyn $\left(\mathrm{A}_{\text {private }}=10\right)$ having almost twice the number of private

379 alleles compared to Llyn Bodlyn and Llyn Padarn before stocking $\left(\mathrm{A}_{\text {private }}=6\right)$. Before the

380 homogenising effects of stocking, Llyn Padarn (Padarn08) showed the highest levels of

381 genetic variability $\left(\mathrm{H}_{\mathrm{O}}=0.80 ; \mathrm{A}_{\mathrm{r}}=6.68\right)$, but also has an alarmingly low estimate of $\mathrm{N}_{\mathrm{e}}\left(\mathrm{N}_{\mathrm{e}}=\right.$

382 5). Such results are indicative of a recent population bottleneck, which is often accompanied

383 by a temporary increase in heterozygosity (Garza and Williamson 2001). Indeed, all three

384 native populations showed evidence of a recent bottleneck $(M=0.293-0.332)$, with Llyn

385 Padarn prior to stocking having one of the lowest estimates of $M(0.293)$ compared to what is

386 expected from this population at equilibrium (0.751). Although hatchery supplementation of

387 Llyn Padarn increased the $\mathrm{N}_{\mathrm{e}}$ from 5 to 54, such stocking practices may have come at the

388 expense of a reduction in genetic uniqueness, with the number of private alleles reducing

389 from 6 to 2 (Table 2). Results from AMOVA reveal a 2.96\% $(P<0.001)$ difference in genetic

390 differentiation between Llyn Padarn before compared to after stocking (Fig. S1). However,

391 we found that genetic variability of Llyn Padarn stayed relatively similar to the levels before

392 stocking $\left(\mathrm{H}_{\mathrm{O}}=6.68\right)$ compared to after stocking $\left(\mathrm{H}_{\mathrm{O}}=6.13\right)$. Nevertheless, our results

393 suggest that the hatchery stock at Crafnant, which is used to supplement Arctic charr for Llyn

394 Padarn, may contain some Llyn Cwellyn genotypes. Salmonid populations are often

395 repeatedly re-stocked over numerous years, not only increasing the likelihood of populations

396 becoming reliant upon hatchery supplementation and at risk of collapse in the absence of 
397 such stocking, but also resulting in reduced recruitment performance of natural populations

398 (Chilcote et al. 2011). For populations to persist in the long term, it is the source of their

399 decline that needs to be addressed before using stock enhancement as a management strategy.

400 However, conservation is also a crisis discipline and such time may rarely be available.

\section{Lack of historical differentiation}

403 All translocated populations showed evidence of founder effects (Table 3), yet such 404 reductions in population size was not reflected by low levels of genetic diversity $\left(\mathrm{H}_{\mathrm{O}}=0.68 \pm\right.$ 405 0.04 SD). These populations primarily consist of Llyn Padarn genotypes, with the exception 406 of Diwaunedd which contains mostly Llyn Cwellyn genotypes (Fig. 2a). The power of this 407 study, based on a relatively small number of microsatellite markers, might have limited our 408 ability to detect any fine-scale population structure that may have existed between Llyn 409 Padarn and Llyn Peris. Although we lack any genetic evidence for such differentiation, 410 previous studies show phenotypic divergence in body size, with Arctic charr in Llyn Padarn 411 growing larger than those in Llyn Peris due to the increased amount of nutrients in Llyn 412 Padarn (Butterworth 1980; McCarthy 2007). Arctic charr are famed for their phenotypic

413 plasticity, whereby multiple morphs can occur in sympatry, diverging in resources (i.e. 414 habitat and diet) and associated trophic morphologies, body size, behaviour and life-history 415 traits (Skúlason et al. 1996, 1999; Klemetsen 2010; Ferguson et al. 2019). Patterns of 416 phenotypic divergence between Llyn Padarn and Llyn Peris indicates differential habitat use 417 and dietary preferences between the two populations (Butterworth 1980; McCarthy 2007).

418 The consideration of both phenotypic and genetic diversity is important to consider in future 419 management actions, since it is this intraspecific biodiversity that can spread the risk of 420 species losses, as differential responses of locally adapted populations can buffer against 421 environmental perturbations (Figge 2004). The historic dispersal between Llyn Padarn and 
422 Llyn Peris may have once buffered the impacts of environmental pressures via

423 metapopulation dynamics (Akçakaya et al. 2007). Although any effects of such loss of gene

424 flow is not reflected by the high levels of genetic diversity, it has likely contributed to the

425 vulnerability of Arctic charr to stochastic environmental events, e.g. the toxic algal bloom in 4262009 (BBC 2010).

\section{Summary}

429 The conservation of genetic diversity is essential to maintain the evolutionary potential of 430 natural populations in response to environmental pressures (Allendorf 2013). Populations in 431 larger habitats are likely to be less susceptible to the loss of such genetic diversity due to 432 bottlenecks because they are not only able to support larger populations, but can also provide 433 more refugial opportunities under adverse conditions (Neville et al. 2009). The increased 434 genetic differentiation in Llyn Bodlyn combined with this populations' low genetic diversity 435 suggests that genetic drift has been the primary cause of genetic divergence, likely due to the 436 lack of habitat availability - an important consideration for maintaining the evolutionary 437 potential of isolated populations (Whiteley et al. 2010). Whilst hatchery supplementation in 438 Llyn Padarn has been successful at increasing short-term $\mathrm{N}_{\mathrm{e}}$, achieving a self-sustaining 439 increase in population abundance depends on numerous factors, including whether stocked 440 fish displace naturally produced offspring, as well as the potential negative impact on the 441 fitness of the wild population (Caroffino et al. 2008). The findings from this study highlight 442 the importance of monitoring the few remaining native populations of Arctic charr in North 443 Wales, as well as ensuring that they retain their genetic integrity. Conservation of this genetic 444 diversity is vital for maintaining evolutionary potential, especially in isolated populations 445 with limited habitat availability. 


\section{References}

458 Adamack AT, Gruber B (2014) PopGenReport: simplifying basic population genetic analyses in R. Methods Ecol Evol 5:384-387. https://doi.org/10.1111/2041-210X.12158

460 Akçakaya HR, Mills M, Doncaster C (2007) The role of metapopulations in conservation. In:

$461 \quad$ Macdonald DW, Service K (eds) Key topics in conservation biology. Blackwell Publishing, Oxford, UK, pp 64-84

463 Allendorf F, England P, Luikart G, et al (2008) Genetic effects of harvest on wild animal populations. Trends Ecol Evol 23:327-337. https://doi.org/10.1016/j.tree.2008.02.008

465 Allendorf FW (2013) Conservation and the genetics of populations, 2nd ed. John Wiley \& 466 Sons, Hoboken

467 Araki H, Berejikian BA, Ford MJ, Blouin MS (2008) Fitness of hatchery-reared salmonids in 468 the wild: Fitness of hatchery fish. Evol Appl 1:342-355. 
470 Araki H, Cooper B, Blouin MS (2007a) Genetic effects of captive breeding cause a rapid,

$471 \quad$ cumulative fitness decline in the wild. Science 318:100-103.

472 https://doi.org/10.1126/science.1145621

473 Araki H, Schmid C (2010) Is hatchery stocking a help or harm? Aquaculture 308:S2-S11. $474 \quad$ https://doi.org/10.1016/j.aquaculture.2010.05.036

475 Araki H, Waples RS, Blouin MS (2007b) A potential bias in the temporal method for 476 estimating Ne in admixed populations under natural selection. Mol Ecol 16:2261477 2271. https://doi.org/10.1111/j.1365-294X.2007.03307.x

478 Archer FI, Adams PE, Schneiders BB (2017) STRATAG $\square$ : An R package for manipulating, 479 summarizing and analysing population genetic data. Mol Ecol Resour 17:5-11. $480 \quad$ https://doi.org/10.1111/1755-0998.12559

481 Balian EV, Segers H, Lévèque C, Martens K (2008) The freshwater animal diversity 482 assessment: an overview of the results. Hydrobiologia 595:627-637.

483 https://doi.org/10.1007/s10750-007-9246-3

484 BBC (2010) "Perfect storm” caused algae on Llyn Padarn lake. 485 http://news.bbc.co.uk/1/hi/wales/north west/8616288.stm. Accessed 16 June 2020 486 Butterworth AJ (1980) The biology of the Arctic char, Salvelinus alpinus L., of Llynnau Peris and Padarn: with special reference to the Dinorwic Reservoir Scheme. Dissertation,

489 Caroffino DC, Miller LM, Kapuscinski AR, Ostazeski JJ (2008) Stocking success of local$490 \quad$ origin fry and impact of hatchery ancestry: monitoring a new steelhead 491 (Oncorhynchus mykiss) stocking program in a Minnesota tributary to Lake Superior. 492 Can J Fish Aquat Sci 65:309-318. https://doi.org/10.1139/f07-167 
493 Ceballos G, Ehrlich PR, Dirzo R (2017) Biological annihilation via the ongoing sixth mass

494 extinction signaled by vertebrate population losses and declines. PNAS 114:E6089-

495 E6096. https://doi.org/10.1073/pnas.1704949114

496 Chilcote MW, Goodson KW, Falcy MR (2011) Reduced recruitment performance in natural

497 populations of anadromous salmonids associated with hatchery-reared fish. Can J Fish

498 Aquat Sci 68:511-522. https://doi.org/10.1139/F10-168

499 Child A (1977) Biochemical polymorphism in char (Salvelinus alpinus L.) from Llynnau

$500 \quad$ Peris, Padarn, Cwellyn and Bodlyn. Heredity 38:359-365

501 Christie MR, Marine ML, French RA, et al (2012a) Effective size of a wild salmonid

502 population is greatly reduced by hatchery supplementation. Heredity 109:254-260.

$503 \quad$ https://doi.org/10.1038/hdy.2012.39

504 Christie MR, Marine ML, French RA, Blouin MS (2012b) Genetic adaptation to captivity can

$505 \quad$ occur in a single generation. PNAS 109:238-242.

$506 \quad$ https://doi.org/10.1073/pnas.1111073109

507 Clabburn P, Davies R, Griffiths J (2014) Summary of the results of hydroacoustic surveys of

508 Llyn Padarn and Llyn Cwellyn, 2013. Natural Resources Wales, Cardiff

509 DCWW (2015) Drought plan 2015. Dŵr Cymru Welsh Water

510 Do C, Waples RS, Peel D, et al (2014) NeEstimator v2: re-implementation of software for the

511 estimation of contemporary effective population size $(\mathrm{Ne})$ from genetic data. Mol

$512 \quad$ Ecol Resour 14:209-214. https://doi.org/10.1111/1755-0998.12157

513 Dray S, Dufour A-B (2007) The ade4 package: implementing the duality diagram for

$514 \quad$ ecologists. J Stat Softw 22:1-20

515 Elner JK, Happey-Wood CM, Wood DGE (1980) The history of two linked but contrasting

516 lakes in North Wales from a study of pollen, diatoms and chemistry in sediment

$517 \quad$ cores. J Ecolo 68:95-121. https://doi.org/10.2307/2259246 
518 Evanno G, Regnaut S, Goudet J (2005) Detecting the number of clusters of individuals using

519 the software structure: a simulation study. Mol Ecol 14:2611-2620.

520 https://doi.org/10.1111/j.1365-294X.2005.02553.x

521 Excoffier L, Smouse PE, Quattro JM (1992) Analysis of molecular variance inferred from

522 metric distances among DNA haplotypes: application to human mitochondrial DNA

523 restriction data. Genetics 131:479-491

524 Ferguson A, Adams C, Jóhannsson M, et al (2019) Trout and char of the North Atlantic Isles.

525 In: Kershner JL, Williams JE, Gresswell RE, Lobón-Cerviá J (eds) Trout and char of

526 the world. American Fisheries Society, Bethesda, Maryland, pp 313-350

527 Figge F (2004) Bio-folio: Applying portfolio theory to biodiversity. Biodiver Conserv

528 13:827-849. https://doi.org/10.1023/B:BIOC.0000011729.93889.34

529 Franklin IR (1980) Evolutionary change in small populations. In: Conservation Biology - An

530 evolutionary-ecological perspective. Sinauer Associates, U.S.A, Sunderland,

$531 \quad$ Massachusetts, pp 135-149

532 Fraser DJ (2008) How well can captive breeding programs conserve biodiversity? A review

533 of salmonids. Evol Appl 0:080602014503553-??? https://doi.org/10.1111/j.1752-

$534 \quad 4571.2008 .00036 . x$

535 Garza JC, Williamson EG (2001) Detection of reduction in population size using data from

536 microsatellite loci. Mol Ecol 10:305-318. https://doi.org/10.1046/j.1365-

$537 \quad$ 294X.2001.01190.x

538 Gomaa NH, Montesinos-Navarro A, Alonso-Blanco C, Picó FX (2011) Temporal variation in 539 genetic diversity and effective population size of Mediterranean and subalpine

$540 \quad$ Arabidopsis thaliana populations. Mol Ecol. https://doi.org/10.1111/j.1365-

541 294X.2011.05193.x 
542 Goudet J (2005) hierfstat, a package for $\mathrm{r}$ to compute and test hierarchical F-statistics. Mol

Ecol Notes 5:184-186. https://doi.org/10.1111/j.1471-8286.2004.00828.x

544 Günther A (1862) Contribution to the Knowledge of the British Charrs. In: Proceedings of

545 the Zoological Society of London. pp 37-54

546 Hatton-Ellis TW (2016) Evidence review of lake nitrate vulnerable zones in Wales. Natural

547 Resources Wales, Bangor

548 Hauser L, Adcock GJ, Smith PJ, et al (2002) Loss of microsatellite diversity and low

549 effective population size in an overexploited population of New Zealand snapper

$550 \quad$ (Pagrus auratus). PNAS 99:11742-11747

551 ICES (2019) Working group on North Atlantic salmon.

$552 \quad$ https://doi.org/10.17895/ICES.PUB.4978

553 IUCN (2019) Global freshwater fish assessment. https://www.iucn.org/theme/species/our-

554 work/freshwater-biodiversity/our-projects/global-freshwater-fish-assessment.

$555 \quad$ Accessed 27 Jun 2020

556 Jombart T (2008) adegenet: a R package for the multivariate analysis of genetic markers.

557 Bioinformatics 24:1403-1405. https://doi.org/10.1093/bioinformatics/btn129

558 Keenan K, McGinnity P, Cross TF, et al (2013) diveRsity $\square$ : An R package for the estimation

559 and exploration of population genetics parameters and their associated errors.

$560 \quad$ Methods Ecol Evol 4:782-788. https://doi.org/10.1111/2041-210X.12067

561 Klemetsen A (2010) The charr problem revisited: Exceptional phenotypic plasticity promotes

562 ecological speciation in postglacial lakes. Freshw Rev 3:49-74.

563 https://doi.org/10.4290/FRJ-3.1.3

564 Kovach R, Jonsson B, Jonsson N, et al (2019) Climate Change and the Future of Trout and

565 Char. In: Kershner JL, Williams JE, Gresswell RE, Lobón-Cerviá J (eds) Trout and

566 char of the world. American Fisheries Society, Bethesda, Maryland, pp 685-716 
567 Lackey RT, Lach D, Duncan S (2006) Salmon 2100: The future of wild Pacific salmon.

$568 \quad$ American Fisheries Society, Bethesda, Md.

569 Laikre L, Schwartz MK, Waples RS, Ryman N (2010) Compromising genetic diversity in the

570 wild: unmonitored large-scale release of plants and animals. Trends Ecol Evol

25:520-529. https://doi.org/10.1016/j.tree.2010.06.013

572 Maitland PS, Winfield IJ, McCarthy ID, Igoe F (2007) The status of Arctic charr Salvelinus

573 alpinus in Britain and Ireland. Ecology Freshw Fish 16:6-19.

$574 \quad$ https://doi.org/10.1111/j.1600-0633.2006.00167.x

575 Mathers RG, De Carlos M, Crowley K, Ó Teangana D (2002) A review of the potential effect

576 of Irish hydroelectric installations on Atlantic salmon (Salmo salar L.) populations,

577 with particular reference to the River Erne. Biol Environ 102:69-79.

$578 \quad$ https://doi.org/10.3318/BIOE.2002.102.2.69

579 McCarthy ID (2007) The Welsh Torgoch (Salvelinus alpinus): A short review of its

580 distribution and ecology. Ecol Freshw 16:34-40. https://doi.org/10.1111/j.1600-

$581 \quad 0633.2006 .00166 . x$

582 Muhlfeld C, Dauwalter D, D'angelo V, et al (2019) Global status of trout and char:

583 Conservation challenges in the twenty-first century. In: Kershner JL, Williams JE,

584 Lobón-Cerviá J (eds) Trout and char of the world. American Fisheries Society, pp

$585 \quad 717-760$

586 Nei M (1973) Analysis of gene diversity in subdivided populations. PNAS 70:3321-3323.

$587 \quad$ https://doi.org/10.1073/pnas.70.12.3321

588 Neville H, Dunham J, Rosenberger A, et al (2009) Influences of wildfire, habitat size, and

589 connectivity on trout in headwater streams revealed by patterns of genetic diversity.

590 Trans Am Fish Soc 138:1314-1327. https://doi.org/10.1577/T08-162.1 
591 Nowak C, Vogt C, Pfenninger M, et al (2009) Rapid genetic erosion in pollutant-exposed

592 experimental chironomid populations. Environ Pollut 157:881-886.

$593 \quad$ https://doi.org/10.1016/j.envpol.2008.11.005

594 Paradis E (2010) pegas: an R package for population genetics with an integrated-modular

595 approach. Bioinformatics 26:419-420. https://doi.org/10.1093/bioinformatics/btp696

596 Pauls SU, Nowak C, Bálint M, Pfenninger M (2013) The impact of global climate change on

597 genetic diversity within populations and species. Mol Ecol 22:925-946.

$598 \quad$ https://doi.org/10.1111/mec.12152

599 Perrier C, Guyomard R, Bagliniere J-L, et al (2013) Changes in the genetic structure of

600 Atlantic salmon populations over four decades reveal substantial impacts of stocking

601 and potential resiliency. Ecol Evol 3:2334-2349. https://doi.org/10.1002/ece3.629

602 Pritchard JK, Stephens M, Donnelly P (2000) Inference of population structure using

603 multilocus genotype data. Genetics 155:945-959

604 Quiñones RM, Johnson ML, Moyle PB (2014) Hatchery practices may result in replacement

605 of wild salmonids: adult trends in the Klamath basin, California. Environ Biol Fishes

606 97:233-246. https://doi.org/10.1007/s10641-013-0146-2

607 R Core Team (2016) R: A language and environment for statistical computing. R Foundation

608 for Statistical Computing, Vienna, Austria

609 Reed DH, Frankham R (2003) Correlation between fitness and genetic diversity. Conserv

$610 \quad$ Biol 17:230-237. https://doi.org/10.1046/j.1523-1739.2003.01236.x

611 Roberts JJ, Fausch KD, Peterson DP, Hooten MB (2013) Fragmentation and thermal risks

612 from climate change interact to affect persistence of native trout in the Colorado River

613 basin. Glob Change Biol 19:1383-1398. https://doi.org/10.1111/gcb.12136 
614 Sgrò CM, Lowe AJ, Hoffmann AA (2011) Building evolutionary resilience for conserving

615 biodiversity under climate change: Conserving biodiversity under climate change.

616 Evol Appl 4:326-337. https://doi.org/10.1111/j.1752-4571.2010.00157.x

617 Skúlason S, Snorrason SS, Jonsson B (1999) Sympatric morphs, populations and speciation

618 in freshwater fish with emphasis on Arctic charr. In: Magurran AE, May RM (eds)

619 Evolution of biological diversity. Oxford, pp 70-92

620 Skúlason S, Snorrason SS, Noakes DL, Ferguson MM (1996) Genetic basis of life history

621 variations among sympatric morphs of Arctic char Salvelinus alpinus. Can J Fish

$622 \quad$ Aquat Sci 53:1807-1813

623 Ursenbacher S, Monney J-C, Fumagalli L (2009) Limited genetic diversity and high

624 differentiation among the remnant adder (Vipera berus) populations in the Swiss and

625 French Jura Mountains. Conserv Genet 10:303-315. https://doi.org/10.1007/s10592-

$626 \quad 008-9580-7$

627 Valiquette E, Perrier C, Thibault I, Bernatchez L (2014) Loss of genetic integrity in wild lake

628 trout populations following stocking: insights from an exhaustive study of 72 lakes

629 from Québec, Canada. Evol Appl 7:625-644. https://doi.org/10.1111/eva.12160

630 Waples RS, Do C (2010) Linkage disequilibrium estimates of contemporary $N_{\mathrm{e}}$ using highly

$631 \quad$ variable genetic markers: a largely untapped resource for applied conservation and

632 evolution. Evol Appl 3:244-262. https://doi.org/10.1111/j.1752-4571.2009.00104.x

633 Weeks AR, Sgro CM, Young AG, et al (2011) Assessing the benefits and risks of

634 translocations in changing environments: a genetic perspective: Translocations in

635 changing environments. Evol Appl 4:709-725. https://doi.org/10.1111/j.1752-

$636 \quad 4571.2011 .00192 . x$

637 White T (2012) Reasons responsible for the decrease in population size of Llyn Padarn charr 638 (Salvelinus alpinus perisii). Masters thesis 
639 Whiteley AR, Hastings K, Wenburg JK, et al (2010) Genetic variation and effective

640 population size in isolated populations of coastal cutthroat trout. Conserv Genet

11:1929-1943. https://doi.org/10.1007/s10592-010-0083-y

642 Wickham H (2016) ggplot2: elegant graphics for data analysis, Second edition. Springer,

643 Cham

644 Wilson AJ, Gíslason D, Skúlason S, et al (2004) Population genetic structure of Arctic charr,

645 Salvelinus alpinus from northwest Europe on large and small spatial scales. Mol Ecol

$646 \quad$ 13:1129-1142. https://doi.org/10.1111/j.1365-294X.2004.02149.x

647 Winfield IJ, Hateley J, Fletcher JM, et al (2010) Population trends of Arctic charr (Salvelinus

648 alpinus) in the UK: assessing the evidence for a widespread decline in response to

649 climate change. Hydrobiologia 650:55-65. https://doi.org/10.1007/s10750-009-0078-

$650 \quad 1$

651

652 
653 Figure 1 Maps of a) the distribution of native (Padarn, Peris, Bodlyn and Cwellyn) and

654 translocated (Dulyn, Ffynnon Llugwy, Cowlyd and Diwaunedd) Arctic charr populations in

655 North Wales includeed in this study, modified from McCarthy (2007); and b) the historical

656 connection between Llyn peris and Llyn Padarn before the construction of a hydropower

657 dam, modified from (Elner et al. 1980).

658

659 Figure 2 Results from a) STRUCTURE and b) Discriminant Analysis of Principle Components

660 (DAPC) demonstrating the genetic groupings of genotypes according to the most likely

661 number of clusters determined by $\Delta k$. Symbols correspond to different clusters (i.e. genetic

662 group). 
663 Table 1 A summary of the number of adult Arctic charr (Salvelinus alpinus) caught and used

664 as hatchery broodstock, as well as the number of offspring successfully released into Llyn

665 Crafnant as a back-up population, and Llyn Padarn.

\section{6}

\begin{tabular}{|c|c|c|c|c|c|c|c|c|c|}
\hline & & & & & & \multicolumn{4}{|c|}{ Offspring released } \\
\hline & \multicolumn{5}{|c|}{ Hatchery broodstock } & \multicolumn{2}{|c|}{ Llyn Crafnant } & \multicolumn{2}{|c|}{ Llyn Padarn } \\
\hline & Sex & Total & Used & $\begin{array}{c}\text { Mean } \\
\text { weight }(g)\end{array}$ & $\begin{array}{c}\text { Mean } \\
\text { length }(\mathbf{m m})\end{array}$ & Fry & Parr & Fry & Parr \\
\hline \multirow{2}{*}{2009} & Male & 24 & 22 & 257 & 303 & & \multirow{4}{*}{600} & & \\
\hline & Female & 29 & 23 & 225 & 289 & & & & \\
\hline \multirow{2}{*}{2010} & Male & 16 & 10 & 333 & 309 & & & & \\
\hline & Female & 79 & 12 & 317 & 312 & & & & \\
\hline \multirow{2}{*}{2011} & Male & 3 & 3 & 244 & 295 & \multirow{2}{*}{4700} & \multirow{2}{*}{1600} & & \multirow{2}{*}{1000} \\
\hline & Female & 14 & 8 & 184 & 270 & & & & \\
\hline \multirow{2}{*}{2012} & Male & 18 & 14 & 213 & 277 & \multirow{2}{*}{500} & \multirow{2}{*}{650} & \multirow{2}{*}{500} & \multirow{2}{*}{650} \\
\hline & Female** & 38 & 23 & 195 & 270 & & & & \\
\hline \multirow{2}{*}{2013} & Male & 5 & 5 & 286 & 298 & & & & \multirow{2}{*}{5700} \\
\hline & Female & 11 & 11 & 219 & 283 & & & & \\
\hline
\end{tabular}

* indicates the number of charr caught that were already fin clipped (i.e. hatchery-reared)

667 
668 Table 2 The number of known Arctic charr populations in North Wales and their status', modified from McCarthy (2007).

\begin{tabular}{|c|c|c|c|c|c|c|c|c|}
\hline Lake & NGR & $\begin{array}{c}\text { Altitude } \\
\text { (m) }\end{array}$ & $\begin{array}{c}\text { Surface } \\
\text { area } \\
\text { (ha) }\end{array}$ & $\begin{array}{c}\text { Max. } \\
\text { depth (m) }\end{array}$ & Use of waterbody & $\begin{array}{l}\text { Date of } \\
\text { transfer }\end{array}$ & Status & $\begin{array}{c}\text { Other salmonid } \\
\text { species }\end{array}$ \\
\hline \multicolumn{9}{|c|}{ Native populations } \\
\hline Llyn Padarn ${ }^{\mathrm{a}}$ & SH572613 & 108 & 102 & 29 & Recreation & & Declining & S. trutta, S. salar \\
\hline Llyn Peris & SH591594 & 111 & 37 & 34 & Pump storage reservoir & & Extinct & \\
\hline Llyn Cwellyn $^{a}$ & SH560549 & 146 & 89 & 40 & Water supply & & Declining & S. trutta, S. salar \\
\hline Bodlyn $^{a}$ & SH648239 & 385 & 16 & 22 & Water supply & & Unknown & S. trutta \\
\hline \multicolumn{9}{|c|}{ Translocated populations } \\
\hline Ffynnon Llugwy & SH692627 & 550 & 15 & 45 & Reservoir & $1976-1981$ & Resident, healthy & S. trutta \\
\hline Llyn Dulyn ${ }^{\mathrm{a}}$ & SH700665 & 538 & 13 & 58 & Reservoir & $1982-1985$ & Resident, healthy & S. trutta \\
\hline Llyn Cowlyd $^{\mathrm{a}}$ & SH727623 & 370 & 116 & 68 & Reservoir & & Resident, healthy & S. trutta \\
\hline Llynnau Diwaunedd $^{\mathrm{a}}$ & SH682537 & 371 & $7 \& 5$ & & None & & Resident, unknown & S. trutta \\
\hline Llyn Coedty & SH754666 & 277 & 5 & & Reservoir & & Transient & S. trutta \\
\hline Llyn Eigiau & SH720652 & 375 & 46 & 10 & Reservoir & & Transient & S. trutta \\
\hline Llyn Crafnant ${ }^{\mathrm{a}}$ & SH750611 & 183 & 25 & 22 & Reservoir & & Hatchery stock from Llyn Padarn & S. trutta \\
\hline
\end{tabular}

${ }^{a}$ Populations included in this study

\section{NGR, National Grid Reference}


Table 3 Genetic diversity indices of eight populations of Arctic charr (Salvelinus alpinus) in North Wales. Effective population sizes $\left(\mathrm{N}_{\mathrm{e}}\right)$ are

675 given for all native populations, including before (Padarn08) and after (Padarn13) stocking in Llyn Padarn.

\begin{tabular}{|c|c|c|c|c|c|c|c|c|c|c|c|c|c|}
\hline Population & $\mathbf{N}$ & $\mathbf{N}_{\mathbf{A}}$ & $\mathbf{A}_{\mathbf{r}}$ & $\mathbf{A}_{\text {private }}$ & $\mathbf{H}_{\mathbf{O}}$ & $\mathbf{H}_{\mathbf{E}}$ & $\mathrm{F}_{\text {IS }}(95 \% \mathrm{CI})$ & HWE & HWE (glb) & HWE (hom) & HWE (het) & $\mathbf{N}_{\mathrm{e}}$ & $M$ \\
\hline Bodlyn & 29 & 40 & 3.39 & 6 & 0.30 & 0.39 & $0.28(0.11,0.40)$ & A & 0.000 & 0.986 & 0.000 & 306 & 0.318 \\
\hline Cowlyd & 48 & 72 & 6.09 & 1 & 0.71 & 0.74 & $0.03(-0.06,0.09)$ & A, B & 0.000 & 0.992 & 0.000 & - & 0.309 \\
\hline Crafnant & 48 & 74 & 5.98 & 6 & 0.67 & 0.73 & $0.06(-0.02,0.13)$ & $\mathrm{A}, \mathrm{F}, \mathrm{G}$ & 0.000 & 0.796 & 0.000 & - & 0.318 \\
\hline Cwellyn & 37 & 85 & 6.10 & 10 & 0.61 & 0.66 & $0.07(-0.05,0.18)$ & & 0.036 & 0.997 & 0.000 & 35 & 0.332 \\
\hline Diwaunedd & 11 & 41 & 5.00 & 0 & 0.73 & 0.66 & $-0.12(-0.33,0.00)$ & & 0.360 & 0.669 & 0.993 & - & 0.219 \\
\hline Dulyn & 32 & 65 & 6.03 & 1 & 0.62 & 0.73 & $0.16(0.06,0.23)$ & $\mathrm{B}$ & 0.003 & 1.000 & 0.000 & - & 0.305 \\
\hline Fynnon Llugwy & 48 & 73 & 5.88 & 4 & 0.64 & 0.70 & $0.06(-0.02,0.13)$ & $\mathrm{A}, \mathrm{C}$ & 0.000 & 0.869 & 0.000 & - & 0.325 \\
\hline Padarn08 & 21 & 61 & 6.68 & 6 & 0.80 & 0.76 & $-0.07(-0.19,0.00)$ & $\mathrm{B}, \mathrm{C}, \mathrm{D}, \mathrm{F}, \mathrm{G}$ & 0.000 & 0.037 & 0.007 & 5 & 0.293 \\
\hline Padarn13 & 33 & 71 & 6.13 & 2 & 0.68 & 0.72 & $0.04(-0.07,0.13)$ & $\mathrm{A}, \mathrm{B}$ & 0.000 & 0.982 & 0.002 & 54 & 0.309 \\
\hline
\end{tabular}

$676 \mathrm{~A}=$ SalD39; $\mathrm{B}=$ SalF56; $\mathrm{C}=$ SalJ81; D = SalP61; E = Ssa406; F = Ssa85; G = SsaD48.

$677 \mathrm{~N}$, sample number; $\mathrm{N}_{\mathrm{A}}$, number of alleles; $\mathrm{A}_{\mathrm{r}}$, rarefied allelic richness; $\mathrm{A}_{\text {private }}$, number of private alleles; $\mathrm{H}_{\mathrm{O}}$, observed heterozygosity; $\mathrm{H}_{\mathrm{E}}$,

678 expected heterozygosity; $\mathrm{F}_{\mathrm{IS}}$, inbreeding coefficients with $95 \%$ confidence intervals $(\mathrm{CI}) ; \mathrm{N}_{\mathrm{e}}$, effective population size; $M$, ratio of the number of

679 microsatellite alleles to the allele size range, with those values less than expected at equilibrium being indicative of a population bottleneck or

680 founder effect regardless of the range of inital $\mathrm{N}_{\mathrm{E}}$.

681 Significant deviations from Hardy-Weinberg Equilibrium (HWE) per loci (A-G).

$682 P$ values for global (glb) HWE, homozygosity excess (hom) and heterozygosity excess (het).

683 Significant $P$ values $(P<0.05)$ indicated in bold. 
684 Table 4 Pairwise $\mathrm{F}_{\mathrm{ST}}$ between all pairs of Arctic charr populations in North Wales, with those significant values $(\mathrm{P}<0.05)$ in bold.

\begin{tabular}{|c|c|c|c|c|c|c|c|c|}
\hline & Bodlyn & Cowlyd & Crafnant & Cwellyn & Diwaunedd & Dulyn & Ffynnon Llugwy & Padarn08 \\
\hline Cowlyd & 0.247 & & & & & & & \\
\hline Crafnant & 0.228 & 0.034 & & & & & & \\
\hline Cwellyn & 0.262 & 0.107 & 0.122 & & & & & \\
\hline Diwaunedd & 0.281 & 0.041 & 0.054 & 0.047 & & & & \\
\hline Dulyn & 0.271 & 0.015 & 0.035 & 0.124 & 0.063 & & & \\
\hline Ffynnon Llugwy & 0.267 & 0.011 & 0.040 & 0.116 & 0.043 & 0.014 & & \\
\hline Padarn08 & 0.269 & 0.021 & 0.031 & 0.120 & 0.085 & 0.018 & 0.025 & \\
\hline Padarn13 & 0.275 & 0.014 & 0.019 & 0.118 & 0.059 & 0.018 & 0.016 & 0.023 \\
\hline
\end{tabular}


686 Table 5 Analysis of molecular variance (AMOVA) to detect population differentiation in

687 Arctic charr in North Wales for: 1) Llyn Padarn before and after stocking, and 2) all stocked

688 lakes versus unstocked lakes (excluding Crafnant and Padarn13). Significant differences in

689 bold.

\begin{tabular}{|c|c|c|c|c|c|c|c|}
\hline Source of variation & DF & SS & MS & Sigma & Variation $(\%)$ & Phi & $P$ \\
\hline \multicolumn{8}{|l|}{ Analysis of Padarn before and after stocking } \\
\hline Between stocks (before and after stocking) & 1 & 13.61 & 13.61 & 0.16 & 2.96 & $\mathbf{0 . 0 3}$ & 0.001 \\
\hline Between indiviuals within Stocked & 52 & 280.78 & 5.40 & 0.16 & 3.02 & 0.03 & 0.169 \\
\hline Within individuals & 54 & 274 & 5.07 & 5.07 & 94.02 & 0.06 & 0.065 \\
\hline Total & 107 & 568.39 & 5.31 & 5.40 & 100 & & \\
\hline \multicolumn{8}{|l|}{$\begin{array}{l}\text { Analysis of stocked versus unstocked lakes (no } \\
\text { Crafnant/Padarn13) }\end{array}$} \\
\hline Between stocked and unstocked & 1 & 166.14 & 166.1 & 0.44 & 6.87 & 0.07 & 0.032 \\
\hline Between populations within stocked/unstocked & 5 & 322.09 & 64.42 & 0.95 & 14.88 & 0.16 & 0.001 \\
\hline Between individuals within population & 219 & 1214.83 & 5.547 & 0.53 & 8.22 & 0.11 & 0.001 \\
\hline Within individuals & 226 & 1015.38 & 4.493 & 4.49 & 70.03 & 0.30 & 0.001 \\
\hline Total & 451 & 2718.43 & 6.028 & 6.42 & 100.00 & & \\
\hline
\end{tabular}

690

691 DF, degrees of freedom; SS, sum of squares; MS, mean squares

692

693

694

695 


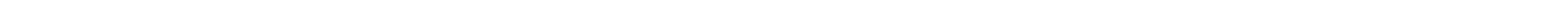


a) Bodlyn $(\mathrm{n}=29)$

Cowlyd

$(\mathrm{n}=48)$

Crafnant

b)

$(\mathrm{n}=48)$

Cwellyn

$(\mathrm{n}=37)$

$(\mathrm{n}=11)$

Dulyn

$(\mathrm{n}=32)$

Ffynnon

Llugwy

$(\mathrm{n}=48)$

Padarn08

$(\mathrm{n}=21)$

Cwellyn/Bodlyn

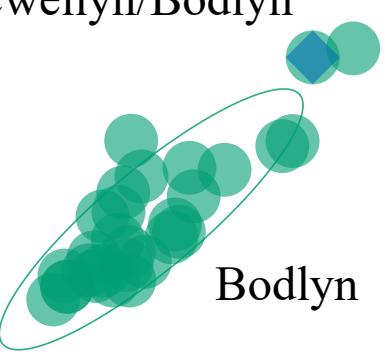

Cluster 1

Cluster 2

Cluster 3

Cwellyn

Diwaunedd

Padarn13

$(\mathrm{n}=33)$ 